\title{
Analisis Tingkat Metakognisi Peserta Didik dalam Memecahkan Masalah Matematika
}

\author{
Nopyta Intan Sari ${ }^{*}$, Amrullah ${ }^{2}$, Syahrul Azmi², Ketut Sarjana ${ }^{2}$ \\ ${ }^{1}$ Mahasiswa Pendidikan Matematika, Universitas Mataram, Mataram, Indonesia \\ 2 Pendidikan Matematika, Universitas Mataram, Mataram, Indonesia \\ *Corresponding Author e-mail: nopyta.intansari@gmail.com
}

Received: 27-01-2021; Revised:04-03-2021; Published: 25-03-2021

\begin{abstract}
Metacognition is the students awareness about their thought processes and monitoring their thought processes. One of thought processes which referred is problem solving ability. In problem-solving the students were different levels of metacognition. Level of metacognition consists of tacit use, aware use, strategic use, dan reflektive use. The purpose of this study was to determine the level of metacognition of students in solving problems and the relationship between mathematical problem solving abilities and the level of metacognition. The research was conducted by giving test instruments to 23 sample students. This research was a descriptive research with qualitative and quantitative approaches. Qualitative data analysis used flow models method with the stages of data reduction, data presentation and drawing conclusions. Furthermore, quantitative data analysis used spearman rank correlation. After the data analysis process, the results of the research were metacognition level of class IX students consisting of tacit use, aware use, and strategic use with percentages of $80 \%, 15 \%$, and $5 \%$. Furthermore, relationship between problem solving ability and the level of metacognition are in the very high category with a correlation coefficient of 0.68 . Therefore, when the problemsolving ability increases, the level of metacognition also increases.
\end{abstract}

Keywords: Level of metacognition; Metacognition, Problem-solving skill.

\begin{abstract}
Abstrak
Metakognisi merupakan kesadaran siswa tentang proses berpikir dan memonitor proses berpikir yang dilakukan. Proses berpikir yang dimaksud adalah kemampuan dalam melakukan pemecahan masalah dengan tingkat metakognisi yang berbeda-beda. Tingkat metakognisi peserta didik terdiri dari tacit use, aware use, strategic use, dan reflektive use. Tujuan dalam penelitian ini adalah untuk mengetahui tingkat metakognisi peserta didik dalam memecahkan masalah dan hubungan antara kemampuan pemecahan masalah matematika dan tingkat metakognisi. Penelitian ini dilakukan dengan memberikan instrumen tes kepada 23 orang peserta didik. Penelitian ini merupakan penelitian deskriptif dengan pendekatan kualitatif dan kuantitatif. Analisis data kualitatif menggunakan metode Flow Models dengan tahapan reduksi data, penyajian data dan penarikan kesimpulan. Selanjutnya, untuk analisis data kuantitatif menggunakan korelasi Rank Spearman. Setelah proses analisis data diperoleh hasil penelitian yaitu tingkat metakognisi peserta didik terdiri dari tacit use, aware use, dan strategic use dengan persentase sebesar 80\%, 15\%, dan 5\%. Lebih lanjut, hubungan antara kemampuan pemecahan masalah dan tingkat metakognisi berada pada kategori sangat tinggi dengan koefisien korelasi 0,68. Oleh karena itu, ketika kemampuan pemecahan masalah meningkat maka tingkat metakognisi juga meningkat.
\end{abstract}

Kata Kunci: Kemampuan Pemecahan Masalah, Metakogniti; Tingkat Metakognisi.

Cara Mengutip

Sari, N. I., Amrullah, A., Azmi, S., \& Sarjana, K.. (2021). Analisis tingkat metakognisi peserta didik dalam memecahkan masalah matematika. Griya Journal of Mathematics Education and Application, 1(1), 36-43. 


\section{PENDAHULUAN}

Matematika merupakan salah satu ilmu yang mendasari perkembangan teknologi dan mempunyai peran penting dalam berbagai disiplin ilmu. Berdasarkan data yang diperoleh dari guru kelas VIII di suatu SMP di Kabupaten Lombok Barat, nilai rata-rata ujian akhir semester genap mata pelajaran matematika tahun ajaran 2018/2019 sebagai berikut; VIII A 37,56, VIII B 39,78, VIII C 35,97, dan VIII D 38,78. Hal itu menunjukkan bahwa hasil belajar peserta didik berada di bawah KKM (kriteria ketuntasan minimal) yang diberikan sekolah yaitu 75 . Salah satu yang mempengaruhi hasil belajar adalah kemampua peserta didik dalam memecahkan masalah.

Menurut Permendiknas Nomor 22 Tahun 2006, salah satu tujuan pembelajaran matematika pada pendidikan menengah adalah peserta didik diharapkan memiliki kemampuan memecahkan masalah yang meliputi kemampuan memahami masalah, merancang model matematika, menyelesaikan model dan menafsirkan solusi yang diperoleh. Dalam memecahkan masalah, peserta didik menggali informasi dari konsep yang sudah diketahui lalu dihubungkan dengan konsep lain, dan diolah untuk menemukan strategi yang tepat dalam menyelesaikan masalah yang ada. Peserta didik harus mengetahui permasalahannya, langkah-langkah yang harus diambil, dan ketepatan pekerjaannya. Peserta didik mampu memecahkan masalah dalam matematika apabila ia memahami masalah yang ditemui serta memahami prosedur atau aturan yang digunakan dalam menyelesaikan masalah tersebut. Untuk itu peserta didik memerlukan strategi-strategi tertentu dalam memecahkan masalah.

Namun, berdasarkan hasil wawancara yang dilakukan pada bulan Mei tahun 2019 dengan salah satu guru matematika di suatu SMP di Kabupaten Lombok Barat, diketahui bahwa sebagian besar peserta didik mengalami kesulitan dalam memecahkan masalah matematika dengan tahapan-tahapan yang dikemukakan para ahli, salah satunya Polya (1973), yaitu memahami masalah, memikirkan rencana, melaksanakan rencana, dan memeriksa kembali. Tahapan tersebut sejalan dengan karakteristik keterampilan metakognisi yang merupakan komponen metakognisi yaitu merencanakan, memantau, dan menilai (evaluasi). Karena metakognisi merupakan kesadaran peserta didik akan proses berfikirnya (Chairani, 2016).

Lebih lanjut dijelaskan dalam Permendiknas No 20 Tahun 2016 bahwa metakognisi diartikan sebagai pengetahuan tentang kekuatan dan kelemahan diri sendiri dan menggunakannya dalam pembelejaran. Istilah meta berasal dari bahasa Yunani artinya lebih tinggi (bandingkan dengan metafisik, metaempiris, metafora, metaetika dan lainlain). Metakognisi secara etimologis artinya sesuatu yang lebih tinggi dari atau diatas kognisi, termasuk pengetahuan kognisi itu sendiri. Lebih lanjut dijelaskan, menurut Flavell, metakognisi dikatakan sebagai: "kognisi tentang kognisi" atau "mengetahui tentang mengetahui". Metakognisi mencakup 2 aspek, yaitu pengetahuan metakognitif dan aktivitas metakognitif atau dalam istilah lain self regulated (Mulyadi et al., 2016). 
Namun, setiap peserta didik memiliki kesadaran (sikap/perilaku) yang berbeda dalam menyelesaikan masalah. Ada yang secara sadar dengan semua yang dikerjakan dan ada juga yang tidak menyadari hal-hal yang dikerjakan. Menurut Swartz dan Perkins metakognisi terbagi menjadi 4 tingkat yaitu tacit use (penggunaan pemikiran tanpa kesadaran), aware use (penggunaan pemikiran dengan kesadaran), strategic use (penggunaan pemikiran yang bersifat strategis) dan reflektive use (penggunaan pemikiran yang bersifat reflektif) (Sophianingtyas \& Sugiarto, 2013). Salah satu aspek dalam diri peserta didik yang perlu dikembangkan untuk menunjang kemampuannya dalam memecahkan masalah adalah proses metakognitif. Hal ini menunjukkan bahwa terdapat hubungan antara kemampuan pemecahan masalah dan tingkat metakognisi artinya ketika kemampuan pemecahan masalah meningkat, tingkat metakognisi juga meningkat (Sutarto \& Syarifudin, 2013).

\section{METODE}

Tujuan dari penelitian ini adalah untuk mengetahui tingkat metakognisi dalam memecahkan masalah matematika peserta didik dan hubungan antara kemampuan pemecahan masalah dan tingkat metakognisi peserta didik. Jenis penelitian ini merupakan deskriptif dengan pendekatan kualitatif dan kuantitatif. Pengambilan data dilakukan pada 22 Oktober 2019 dengan sampel sebanyak 23 peserta didik yang diperoleh dengan teknik cluster random sampling yang sebelumnya dilakukan uji homogen. Setelah sampel terpilih, dilanjutkan dengan pembuatan instrumen yaitu instrumen tes dengan soal-soal pemecahan masalah menggunakan materi yang sudah diajarkan sebelumnya dan pedoman wawancara semiterstruktur yaitu pedoman wawancara yang berisi garis besarnya saja. Setelah instrumen tes dinyatakan valid, instrumen tes tersebut diberikan kepada peserta didik yang menjadi sampel penelitian.

Analisis data dalam penelitian ini terdiri dari analisis data kualitatif dan analisis data kuantitatif. Analisis data kualitatif untuk mengetahui tingkat metakognisi peserta didik dalam memecahkan masalah matematika, metode yang digunakan dalam analisis ini adalah metode Flow Model yang terdiri dari tiga tahap yaitu; reduksi data, penyajian data dan penarikan kesimpulan (Satori et al., 2014). Adapun indikator tingkat metakognisi yang digunakan dalam penelitian ini adalah sebagai berikut:

Tabel 1. Kriteria Tingkat Metakognisi

\begin{tabular}{lrl}
\hline Tingkat Metakognisi & Indikator Tingkat Metakognisi \\
\hline Tacit Use & a. & Peserta didik tidak dapat menjelaskan atau \\
& menuliskan hal yang diketahui atau \\
& ditanyakan \\
b. & Peserta didik tidak mengetahui konsep yang \\
& tepat untuk menyelesaikan masalah \\
c. & Peserta didik tidak melakukan evaluasi \\
& terhadap solusi pemecahan masalah yang \\
& telah dikerjakan \\
\hline Aware Use & a. $\begin{array}{l}\text { Peserta didik memahami masalah dengan } \\
\text { memberikan penjelasan yang tepat }\end{array}$ \\
\hline
\end{tabular}




\begin{tabular}{lr}
\hline Tingkat Metakognisi & Indikator Tingkat Metakognisi \\
\hline b. $\begin{array}{l}\text { Peserta didik menyadari kesalahan konsep } \\
\text { atau cara yang digunakan namun tidak dapat } \\
\text { memperbaikinya }\end{array}$ \\
c. $\begin{array}{l}\text { Peserta didik melakukan evaluasi tetapi tidak } \\
\text { yakin dengan solusi yang diperoleh }\end{array}$ \\
a. $\begin{array}{l}\text { Peserta didik tidak mengalami kesulitan } \\
\text { dalam memilih konsep atau cara yang akan } \\
\text { digunakan dalam menyelesaikan masalah }\end{array}$ \\
b. $\begin{array}{l}\text { Peserta didik menyadari kesalahan konsep } \\
\text { atau cara yang digunakan serta memberikan } \\
\text { argumen yang mendukung pemikirannya } \\
\text { (mencoba-coba, mengecek dan merevisi apa } \\
\text { yang dipikirkan) }\end{array}$ \\
c. Peserta didik melakukan evaluasi tetapi tidak \\
yakin dengan solusi yang diperoleh \\
a. $\begin{array}{l}\text { Peserta didik dapat menjelaskan hal-hal yang } \\
\text { ditulis pada lembar jawaban }\end{array}$ \\
b. Peserta didik menyadari kesalahan konsep \\
atau cara yang digunakan dan \\
memperbaikinya \\
c. Peserta didik melakukan evaluasi secara \\
menyeluruh pada hasil pekerjaannya
\end{tabular}

Selanjutnya, analisis data kuantitatif untuk mengetahui hubungan antara kemampuan pemecahan masalah dan tingkat metakognisi peserta didik, analisis ini menggunakan menggunakan korelasi Rank Spearman (Sugiyono, 2014). Adapun kategori kemampuan pemecahan masalah (Ekawati et al., 2011) yang digunakan dalam analisis ini adalah sebagai berikut:

Tabel 2. Kriteria Penentuan Kategori

\begin{tabular}{lc}
\hline Kategori Hasil Tes & Kriteria \\
\hline Sangat Tinggi & $x \geq M_{i}+1,5 S b_{i}$ \\
Tinggi & $M i+0,5 S b_{i}<x \leq M_{i}+1,5 S b_{i}$ \\
Sedang & $M_{i}-0,5 S b_{i} \leq x<M_{i}+0,5 S b_{i}$ \\
Rendah & $M_{i}-1,5 S b_{i}<x \leq M_{i}-0,5 S b_{i}$ \\
Sangat Rendah & $x \leq M_{i}-1,5 S b_{i}$ \\
\hline
\end{tabular}

\section{HASIL DAN PEMBAHASAN}

\subsection{Hasil}

Berdasarkan analisis data kualitatif dengan metode Flow Model diperoleh bahwa tingkat metakognisi peserta didik, yaitu sebanyak 16 peserta didik berada pada tingkat tacit use dengan persentase $80 \%$, sebanyak 3 peserta didik berada pada tingkat aware use dengan persentase $15 \%$ dan 1 peserta didik berada pada tingkat strategic use dengan persentase $5 \%$. Gambar 1 berikut menunjukkan persentase tingkat metakognisi peserta didik. 


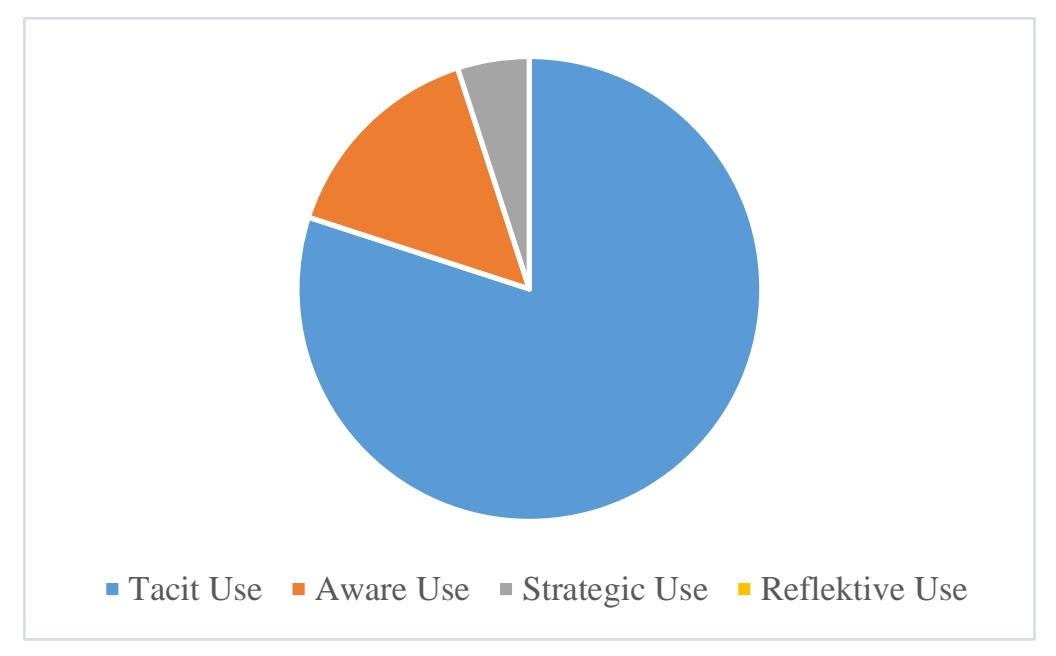

Gambar 1. Persentase Tingkat Metakognisi Peserta Didik

Selanjutnya, hubungan tingkat metakognisi dan kemampuan metakognisi berdasarkan korelasi Rank Spearman diberikan pada Tabel 3 berikut.

Tabel 3. Korelasi Rank Spearman

\begin{tabular}{lcccccc}
\hline Peserta Didik & $\mathrm{X}$ & $\mathrm{rX}$ & $\mathrm{Y}$ & $\mathrm{rY}$ & $b_{i}$ & $b_{i}{ }^{2}$ \\
\hline S1 & 1 & 18 & 1 & 12.5 & 5.5 & 30.25 \\
S2 & 2 & 10.5 & 1 & 12.5 & -2 & 4 \\
S3 & 3 & 3 & 2 & 3 & 0 & 0 \\
S4 & 3 & 3 & 3 & 1 & 2 & 4 \\
S5 & 2 & 10.5 & 1 & 12.5 & -2 & 4 \\
S6 & 3 & 3 & 1 & 12.5 & -9.5 & 90.25 \\
S7 & 2 & 10.5 & 2 & 3 & 7.5 & 56.25 \\
S8 & 1 & 18 & 1 & 12.5 & 5.5 & 30.25 \\
S9 & 2 & 10.5 & 1 & 12.5 & -2 & 4 \\
S10 & 2 & 10.5 & 1 & 12.5 & -2 & 4 \\
S11 & 2 & 10.5 & 1 & 12.5 & -2 & 4 \\
S12 & 3 & 3 & 2 & 3 & 0 & 0 \\
S13 & 2 & 10.5 & 1 & 12.5 & -2 & 4 \\
S14 & 2 & 10.5 & 1 & 12.5 & -2 & 4 \\
S15 & 2 & 10.5 & 1 & 12.5 & -2 & 4 \\
S16 & 2 & 10.5 & 1 & 12.5 & -2 & 4 \\
S17 & 1 & 18 & 1 & 12.5 & 5.5 & 30.25 \\
S18 & 3 & 3 & 1 & 12.5 & -9.5 & 90.25 \\
S19 & 1 & 18 & 1 & 12.5 & 5.5 & 30.25 \\
S20 & 1 & 18 & 1 & 12.5 & 5.5 & 30.25 \\
& & Total & & & & 428 \\
\hline
\end{tabular}

Berdasarkan Tabel 3 tersebut data yang diperoleh diaplikasikan pada rumus korelasi Rank Spearman dan diperoleh koefisien korelasi sebesar 0.68. Artinya kategori keeratan hubungan antara kemampuan pemecahan masalah dan tingkat metakognisi adalah tinggi. Angka koefisien korelasi bernilai positif yaitu 0.68 yang berarti hubungan kedua variabel searah (jika kemampuan pemecahan masalah meningkat maka tingkat metakognisi juga meningkat). Untuk $n=20$ diperoleh rho $(\rho)$ tabel 0.59 untuk taraf 
kesalahan 1\%. Hasil rho $(\rho)$ hitung lebih besar dari rho $(\rho)$ tabel baik untuk taraf kesalahan $1 \%$ artinya terdapat hubungan yang signifikan antara kemampuan pemecahan masalah dan tingkat metakognisi terhadap 20 peserta didik.

\subsection{Pembahasan}

\subsubsection{Peserta Didik dengan Tingkat Tacit Use}

Peserta didik S1 dengan hasil tes sangat rendah, hanya menuliskan hal-hal yang diketahui dan ditanyakan secara tidak lengkap pada soal nomer 1, 2 dan 3. Berdasarkan hasil wawancara peserta didik terlihat mengalami kesulitan dalam menentukan konsep atau rumus yang akan digunakan dalam menyelesaikan masalah. Oleh karena itu, peserta didik hanya dapat menuliskan hal yang diketahui dan ditanyakan sehingga tidak dapat melanjutkan pekerjaan ke tahap berikutnya. Untuk soal nomer 4, dikerjakan dengan konsep yang tidak tepat. Pada saat wawancara juga menunjukkan bahwa peserta didik tidak memahami hal yang dituliskan di lembar jawaban.

Peserta didik S5, S11 dan S16 dengan hasil tes rendah, hanya menuliskan hal-hal yang diketahui dan ditanyakan secara tidak lengkap pada soal nomer 1, 2 dan 3. Berdasarkan hasil wawancara peserta didik terlihat mengalami kesulitan dalam menentukan konsep atau rumus yang akan digunakan dalam menyelesaikan masalah. Oleh karena itu, peserta didik hanya dapat menuliskan hal yang diketahui dan ditanyakan sehingga tidak dapat melanjutkan pekerjaan ke tahap berikutnya. Untuk soal nomer 4, dikerjakan dengan konsep yang tidak tepat sesuai dengan pernyataan pada saat wawancara peserta didik sedikit kesulitan dalam menentukan konsep dalam menyelesaikan masalah, dan tidak menyadari konsep yang digunakan itu salah.

Peserta didik S6 dan S18 dengan hasil tes sedang mengerjakan semua soal, nomer 1 dan 4 dengan konsep yang tidak tepat. Pada saat wawancara peserta didik tidak memahami hal yang dituliskan pada lembar jawaban dan tidak melakukan evaluasi. Untuk soal nomer 3 dan 4, peserta didik mengerjakan dengan konsep yang tepat. Tetapi ketika diwawancarai peserta didik tidak dapat menjelaskan hal yang dituliskan. Hal yang tidak dapat dihindari adalah peserta didik menyalin tulisan temannya. Oleh karena itu, S6 dan S18 berada pada tingkat tacit use.

Berdasarkan uraian diatas disimpulkan bahwa tingkat tacit use tidak hanya dimiliki oleh peserta didik dengan hasil tes sangat rendah, karena dalam tes peserta didik sebagian besar mengerjakan dengan tidak jujur. Hal ini juga sesuai dengan hasil penelitian yang menyatakan bahwa mahasiwa dengan hasil tes tinggi, sedang dan rendah, rata-rata berada pada tingkat tacit use yaitu kesadaran berpikir tanpa mempertimbangkan keputusan yang diambil (Murniati et al., 2017).

\subsubsection{Peserta Didik dengan Tingkat Aware Use}

Peserta didik S3 dengan hasil tes sedang mengerjakan nomer 1 dengan konsep yang tidak tepat, indikator yang dipenuhi yaitu menuliskan yang diketahui dan ditanyakan serta melakukan kesalahan dalam mengerjakan tetapi tidak dapat memperbaikinya. Berdasarkan hasil wawancara peserta didik tidak mengalami kesulitan dalam 
menentukan konsep yang tepat untuk menyelesaikan masalah sehingga soal nomer 2 peserta didik menyelesaikan dengan tepat. Untuk soal nomer 3 dan 4, peserta didik hanya menuliskan diketahui dan ditanyakan. Oleh karena itu, tingkat metakognisi S3 dalam memecahkan masalah adalah aware use.

Peserta didik S7 dengan hasil tes rendah, untuk soal nomer 1, 2 dan 3, peserta didik hanya menuliskan hal yang diketahui dan ditanyakan dengan lengkap. Pada saat wawancara peserta didik menyatakan bahwa soal lumayan sulit untuk diselesaikan tetapi tetap dikerjakan sampai tahap evaluasi dan soal nomer 4 terjawab dengan konsep yang tepat. Oleh karena itu, tingkat metakognisi S7 dalam memecahkan masalah adalah aware use.

\subsubsection{Peserta Didik dengan Tingkat Strategic Use}

Peserta didik S4 dengan hasil tes sedang mengerjakan semua nomer dengan lengkap. Untuk nomer 1 dan 4, peserta didik mengerjakan dengan konsep yang tidak tepat. Untuk nomer 2, peserta didik selama mengerjakan soal menyadari adanya kesalahan lalu memperbaikinya. Soal nomer 3 dikerjakan dengan baik. Meskipun semua soal dikerjakan, pada saat wawancara S4 merasa tidak yakin dengan jawabannya karena merasa rumus-rumus yang diterapkan secara acak-acakan. Oleh karena itu, tingkat metakognisi S4 dalam memecahkan masalah adalah strategic use.

\subsubsection{Hubungan Kemampuan Pemecahan Masalah dan Tingkat Metakognisi}

Berdasarkan hasil penelitian yang sudah dilakukan sejalan dengan pernyataan yang ada bahwa dalam memecahkan masalah peserta didik secara tidak langsung melibatkan metakognisi karena terdapat beberapa aspek dalam diri peserta didik yang perlu dikembangkan untuk menunjang kemampuannya dalam memecahkan masalah yaitu strategi pemecahan masalah, proses metakognitif dan keyakinan serta perilaku peserta didik terhadap matematika. Selanjutnya, metakognisi dapat membantu pelajar untuk menyelesaikan permasalahan melalui perancangan secara efektif, melibatkan proses mengetahui masalah, memahami masalah yang perlu dicari solusinya dan memahami strategi yang efektif untuk menyelesaikannya (Ikram, 2017).

Dapat dilihat dari hasil perhitungan korelasi Rank Spearman bahwa hubungan antara kemampuan pemecahan masalah dan tingkat metakognisi itu tinggi. Adapun beberapa hal yang tidak bisa dihindari antara lain keadaan yang tidak kondusif pada saat pengambilan data sehingga terdapat data-data yang tidak sesuai antara lain ada peserta didik yang mendapat hasil tes tinggi yang berada pada tingkat tacit use. Hal itu disebabkan oleh ketidakjujuran dalam menyelesaikan soal pemecahan masalah. Jika hal ini diteruskan, maka peserta didik tidak akan memahami dirinya sendiri. Oleh karena itu, dengan adanya tingkat metakognisi guru dapat membantu peserta didik untuk memahami dirinya sendiri dan memperbaiki proses pembelajarannya.

\section{PENUTUP}

Berdasarkan hasil analisis data dan pembahasan dapat disimpulkan bahwa tingkat metakognisi peserta didik terdiri dari 3 kategori yaitu tacit use, aware use dan strategic 
use. Tingkat tacit use merupakan tingkat yang paling banyak dimiliki peserta didik dengan persentase $80 \%$. Untuk tingkat yang paling sedikit dimiliki peserta didik adalah strategic use dengan persentase 5\%. Selain itu, tingkat aware use yang berada diantara tacit use dan strategic use dimiliki peserta didik dengan persentase 15\%. Untuk hubungan antara kemampuan pemecahan masalah dan tingkat metakognisi diperoleh berdasarkan koefisien korelasi Rank Spearman yaitu 0,68 yang berada pada kategori tinggi. Artinya, kemampuan pemecahan masalah mempengaruhi tingkat metakognisi sebanyak $68 \%$, dan sisanya $32 \%$ dipengaruhi oleh faktor lain. Angka koefisien korelasi bernilai positif artinya jika kemampuan pemecahan masalah ditingkatkan maka tingkat metakognisi juga akan meningkat.

\section{REFERENSI}

Chairani, Z. (2016). Metakognisi Siswa dalam Pemecahan Masalah Matematika. Yogyakarta: Deepublish.

Ekawati, Estina, \& Sumaryanta. (2011). Pengembangan Instrumen Penilaian Pembelajaran Matematika SD/SMP. Jakarta: Kementerian Pendidikan Nasional.

Ikram, Z. J. W. (2017). Kegiatan Metakognitif dalam Pemecahan Masalah Matematika. Prosiding Seminar Nasional "Tellu Cappa," September, 810-820.

Mulyadi, S., Rahardjo, W., \& Basuki, A. M. H. (2016). Psikologi Pendidikan. Jakarta: PT. Raja Grafindo Persada.

Murniati, Salimi, Y. K., \& Musa, W. J. A. (2017). Tingkat Kemampuan Metakognisi Mahasiswa dalam Menyelesaikan Soal- soal Kinetika Kimia. Jurnal ENTROPI, 12(2), 179-185.

Polya, G. (1973). How to solve it: a new aspect of mathematical method, 2nd ed. Pricenton University Press.

Satori, Djam'an, \& Komariah, A. (2014). Metodologi Penelitian Kualitatif. Bandung: Alfabeta.

Sophianingtyas, F., \& Sugiarto, B. (2013). Identifikasi Level Metakognitif dalam Memecahkan Masalah Materi Perhitungan Kimia. UNESA Journal of Chemical Education, 2(1), 21-27.

Sugiyono. (2014). Statistika untuk Penelitian. Bandung: Alfabeta.

Sutarto, \& Syarifudin. (2013). Desain Pembelajaran Matematika. Yogyakarta: Samudra Biru. 